\title{
Potassium/calcium/nickel oxide catalysts for oxidative coupling of methane
}

\author{
Kerry M. Dooley ${ }^{1}$ and Julian R.H. Ross ${ }^{2}$ \\ Department of Chemical Technology, Technical University of Twente, P.O. Box 217, 7500 EA \\ Enschede (Netherlands)
}

(Received 26 May 1992, revised manuscript received 5 August 1992)

\begin{abstract}
A series of potassium/calcium/nickel oxides were tested for the oxidative coupling of methane (OCM) at $843-943 \mathrm{~K}$ and water addition to the feed at $0-65 \mathrm{~mol}-\%$. The $\mathrm{K} / \mathrm{Ni}$ ratios varied from $0.0-0.6$ and $\mathrm{Ca} / \mathrm{Ni}$ from 0.0-11; catalysts with no nickel were also tested. At least $10 \%$ water in the feed and temperatures lower than ca. $940 \mathrm{~K}$ were necessary to keep nickel-containing catalysts from converting to purely steam reforming/combustion behavior. Catalysts of low (less than 4) $\mathrm{Ca} / \mathrm{Ni}$ were the most active, with a maximum $\mathrm{C}_{2}$ selectivity, which increased with temperature, of $37 \%$ at $11 \% \mathrm{C}_{2}$ yield (28\% water in feed, $933 \mathrm{~K}$ ). Catalysts of high (4-11) $\mathrm{Ca} / \mathrm{Ni}$ ratio were less active, with a maximum $\mathrm{C}_{2}$ selectivity of $32 \%$ at $7.1 \% \mathrm{C}_{2}$ yield ( $43 \%$ water in feed, $923 \mathrm{~K}$ ). Previous claims of higher selectivities for similar catalysts could not be reproduced except at short times on stream, in the absence of substantial carbonate buildup. These transient selectivities were not associated with the nickel-containing phase. At steady state, both $\mathrm{C}_{2}$ yields and selectivities increased with respect to the water content of the feed, while decreasing with $\mathrm{C}_{1} / \mathrm{O}_{2}$ ratio. The latter behavior is unusual and may be related to the reduction of higher valent potassium/calcium/nickel oxide. The existence of such material as an active phase for OCM was suggested by the results of X-ray diffraction, differentional scanning calorimetry, temperature-programmed reduction, and laser Raman spectroscopic characterizations of fresh and used catalysts.
\end{abstract}

Keywords: alkali nickel oxide, methane, oxidative coupling.

\section{INTRODUCTION}

Group VIII transition metal oxides, and some reducible post-transition metal oxides (especially $\mathrm{SnO}_{x}$ ), are materials which have shown promise as pro-

Correspondence to: Prof. K.M. Dooley, Dept. of Chemical Engineering, South Stadium Rd., Louisiana State Univ., Baton Rouge, LA 70803-7303, USA. Tel. (+1-504)3883060, fax. (+1504)3881476, e-mail DOOLEY@LSUCHE.BITNET.

${ }^{1}$ On sabbatical leave from Dept. of Chemical Engineering, Louisiana State Univ., Baton Rouge, LA 70803, USA.

${ }^{2}$ Current address: Dept. of Industrial Chemistry and Chemical Engineering, Univ. of Limerick, Plassey Park, Limerick, Ireland. Tel. (+353-61)333644, fax. (+353-61)330316, e-mail ROSSJ@UL.IE. 
moters for alkali/alkaline earth oxide catalysts used for the oxidative coupling of methane (OCM) [1-8]. The relationship between these materials and alkali molybdate catalysts is at present unclear, but there are X-ray photoelectron spectroscopy (XPS) and other indications of multiple metal oxidation states (e.g., $\mathrm{Ni}^{2+} / \mathrm{Ni}^{3+}$ ) and participation of lattice oxygen in these catalysts at working conditions [1,5-7]; these are characteristics of alkali molybdate catalysts as well. It has recently been discovered by Heinemann and coworkers $[7,8]$ that inclusion of more than $60 \%$ water in the feed to an OCM reactor greatly increases the $\mathrm{C}_{2+}$ selectivity of such catalysts at ca. $873 \mathrm{~K}$, by an as yet unknown mechanism $[7,8]$. This effect of water also parallels experience with the alkali molybdate catalysts, although the selectivity enhancements here are not as pronounced $[9,10]$.

Higher activities (high oxygen conversions at below $1000 \mathrm{~K}$ ), at only slight penalties in selectivity, have also been observed for $\mathrm{Li} / \mathrm{MgO}$ catalysts mixed with small amounts of cobalt or tin oxides $[11,12]$. It has been hypothesized that the presence of a reducible oxidic phase promotes activation of oxygen in a dissociated form suitable for methane activation such as surface $0^{-}$[13]. Electron spin resonance (ESR) measurements on $\mathrm{Co}^{2+} / \mathrm{MgO}$ suggest that $\mathrm{O}^{-}$ would not be formed on the surface of transition metal/alkaline earth oxide mixtures in the absence of alkali [14]. In the presence of alkali, ${ }^{16} \mathrm{O}_{2} /{ }^{18} \mathrm{O}_{2}$ exchange measurements (for $\mathrm{Li} / \mathrm{NiO}$ ) [2] and XPS measurements on adsorbed oxygen (for $\mathrm{K}^{+} / \mathrm{Mn}_{3} \mathrm{O}_{4}$ ) [15] at least suggest that $\mathrm{O}^{-}$may be present, although it is not yet certain that $\mathrm{O}^{-}$is involved in the selective oxidation.

We have begun a study of alkali/alkaline earth/transition metal oxides as catalysts for OCM. That these catalysts may be useful with water-rich feeds has already been demonstrated by Heinemann and coworkers $[7,8]$. However, it remains to be seen whether other catalysts of this type require as much water for high selectivity, and whether activities can be increased above the low levels previously observed. These catalysts may also be effective at conventional conditions (higher temperatures, $\mathrm{C}_{1} / \mathrm{O}_{2}$ ratios $>4$, no water in the feed), but have been only sparingly studied $[1,6]$.

\section{EXPERIMENTAL}

$\mathrm{CaO} / \mathrm{NiO}$ mixed oxides were prepared by coprecipitation of the nitrates at $\mathrm{pH}=12$, with slight heating, followed by calcination in static air. For some of the catalysts the potassium source was coprecipitated as well; but in most of the preparations $\mathrm{KNO}_{3}$ was added to the already calcined $\mathrm{CaO} / \mathrm{NiO}$ by dry mixing, because otherwise retention of potassium was poor. This latter procedure is in accord with that of Pereira et al. [7].

At each $\mathrm{Ca} / \mathrm{Ni}$ ratio, catalysts of low (K/Ni ca. 0.1$)$ and high (K/Ni ca. 0.5) potassium content were prepared. Final calcination was in-situ prior to kinetics experiments using one of the following procedures: 
(A) $3 \mathrm{~cm}^{3} / \mathrm{min} \mathrm{O}_{2}, 973 \mathrm{~K}, 40 \mathrm{~h}$

(B) $3 \mathrm{~cm}^{3} / \mathrm{min} \mathrm{O}_{2}, 1013 \mathrm{~K}, 40 \mathrm{~h}$

(C) $3 \mathrm{~cm}^{3} / \min \mathrm{CO}_{2}, 773 \mathrm{~K}, 4 \mathrm{~h}$; then $2 \mathrm{~cm}^{3} / \min \mathrm{O}_{2}+1 \mathrm{~cm}^{3} / \min \mathrm{CO}_{2}, 973 \mathrm{~K}$, $12 \mathrm{~h}$

(D) same as (C) except $40 \mathrm{~h}$ at $973 \mathrm{~K}$

Procedures (C) and (D) were designed to convert $\mathrm{KNO}_{3}$ to the carbonate before high-temperature calcination, in order to reduce potassium loss by vaporization. The catalysts were pressed and crushed to $0.3-0.6 \mathrm{~mm}$ grains prior to these treatments. A K.05/Ca catalyst (no nickel) was prepared following the procedure of Rasko et al. [8]; the final calcination was at $973 \mathrm{~K}$ for $18 \mathrm{~h}$ in $3 \mathrm{~cm}^{3} / \min$ air.

Alkali and alkaline earth analyses were carried out using atomic absorption spectroscopy (AAS), while transition metal concentrations were determined by X-ray fluorescence (XRF). The catalysts are designated in terms of the atomic ratios of potassium/calcium/nickel. The initial $\mathrm{Ca} / \mathrm{Ni}$ ratio in all cases decreased somewhat upon calcination due to absorption of $\mathrm{CaO}$ by the combustion boats. The ratios given here were measured after the final calcination, but prior to OCM reaction.

X-ray diffraction (XRD) measurements were made on a Philips P.W. 1710 diffractometer using $\mathrm{Cu} \mathrm{K} \alpha$ radiation at $1.5418 \AA$. Differential scanning calorimetry (DSC) measurements were made using a Stanton Redcroft PL 700 DSC using oxygen, nitrogen, air, or a $50 \% \mathrm{H}_{2} / 50 \% \mathrm{~N}_{2}$ mixture as the carrier gas, at $30-40 \mathrm{~cm}^{3} / \mathrm{min}$. Thermogravimetric analyses (TGA) with temperature programs and gas flow-rates simulating final in-situ calcinations were performed using a DuPont 951 TGA. For laser Raman spectroscopy, the $514.5 \mathrm{~nm}$ line of an $\mathrm{Ar}^{+}$laser at $20 \mathrm{~mW}$ was used for excitation. A triple monochromator (Spex 1877) was used with $100 \mathrm{~s}$ accumulation of signal. Samples were powdered, pressed, and mounted on glass slides.

The kinetics measurements were performed in a conventional microreactor flow system with on-line gas chromatography (GC) analysis. The reactor was $1.25 \mathrm{~cm}$ I.D. with a $10 \mathrm{~cm}$ bed length, with the catalyst held between $0.3-0.6$ mm quartz beads. The $C_{1} / O_{2}$ ratio was $2.3-2.7$ unless otherwise noted, and the methane weight hourly space velocity (WHSV) was $0.40 \pm .0 .01 \mathrm{~h}^{-1}$ with total flow-rates in the range $30-50 \mathrm{~cm}^{3} / \mathrm{min}$. Methane, oxygen, and helium (if used) were metered and mixed using Brooks 5850 mass flow controllers. When water was added to the feed, it was supplied from a saturator which was controlled by a constant $( \pm 1 \mathrm{~K})$ temperature bath.

\section{RESULTS}

\section{Catalyst activity measurements}

Blank runs (quartz beads only) at 16 and $27 \%$ water in the feed were performed using a feed of molar ratio $\mathrm{CH}_{4} / \mathrm{C}_{2} \mathrm{H}_{6} / \mathrm{O}_{2}=2 / 2 / 1$. This feed simulated 
a normal feed that has undergone $50 \%$ oxygen conversion to produce ethane selectively. The purpose of this experiment was to determine how much of the ethane produced by the catalyst under best-case conditions might have been decomposed to $\mathrm{CO}_{x}$ in gas-phase reactions. This is a more stringent test of the effects of post-reactor dead volume than a blank experiment with only a $\mathrm{CH}_{4}$ / $\mathrm{O}_{2} / \mathrm{H}_{2} \mathrm{O}$ feed. At the highest temperature studied, $936 \mathrm{~K}$, the total carbon conversions found using this mixed feed were $18 \%$ (for $16 \%$ water in the feed) and $17 \%$ (27\% water), with $\mathrm{CO}_{x}$ selectivities of $28 \%$ (16\% water) and $27 \%(27 \%$ water), respectively; the oxygen was completely converted. From these numbers it can be calculated that at our normal reactor conditions only at most ca. $5 \%$ of the total carbon could react to $\mathrm{CO}_{x}$ by reactions not occurring on the catalysts. For a typical methane conversion of $30 \%$, this corresponds to an achievable $\mathrm{C}_{2+}$ selectivity of ca. $80 \%$ at worst case conditions.

Except at short times-on-stream, the carbon balances for all data reported here were within $10 \%$, most within $5 \%$; the hydrogen balances were within $5 \%$. The oxygen conversions for the nickel-containing catalysts were near $100 \%$ at temperatures higher than $903 \mathrm{~K}$; when the $\mathrm{Ca} / \mathrm{Ni}$ ratio was low, they were near $100 \%$ except below $873 \mathrm{~K}$. The oxygen conversions for the $\mathrm{K} .05 / \mathrm{Ca}$ catalyst were typically $0-50 \%$ except when the feed $\mathrm{C}_{1} / \mathrm{O}_{2}$ ratio was high.

The effects of the four different calcination procedures on the performance of a single representative catalyst (K.1/Ca1.2/Ni) was first examined. Fig. 1 shows the results of reaction experiments at different temperatures, including a repeat measurement after longer term $(>12 \mathrm{~h})$ use. In this and all subsequent figures, such a repeat measurement is denoted by a line connecting the repeat datum to the datum at highest temperature; in other words, the exact temperature progression used in the experiment is shown.

It is evident from Fig. 1 that calcination in the absence of carbon dioxide resulted in a catalyst with poorer stability. Calcination in the presence of car-

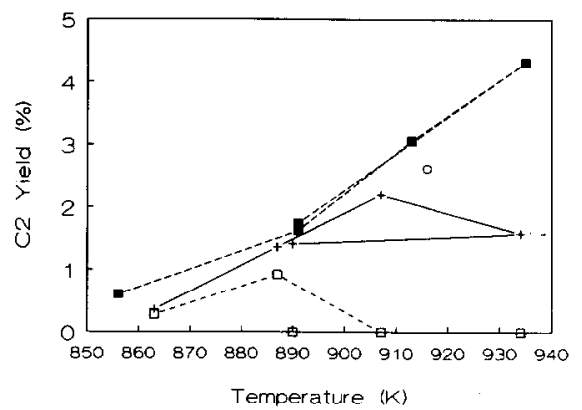

Fig. 1. Effect of calcination conditions, K.1/Ca1.2/Ni catalyst, $\mathrm{C}_{1} / \mathrm{O}_{2} \mathrm{ca} .2 .5$. ( + ) (A) $973 \mathrm{~K}, 40$ $\mathrm{h}, 3 \mathrm{~cm}^{3} / \min \mathrm{O}_{2}$; (口) (B) same as A but $1013 \mathrm{~K}$; (D) (C) $773 \mathrm{~K}, 4 \mathrm{~h}, 3 \mathrm{~cm}^{3} / \mathrm{min} \mathrm{CO}_{2}$, then 973 $\mathrm{K}, 12 \mathrm{~h}, 2 \mathrm{~cm}^{3} / \mathrm{min} \mathrm{O}_{2}+1 \mathrm{~cm}^{3} / \mathrm{min} \mathrm{CO}_{2} ;(\mathrm{O})$ (D) same as $\mathrm{C}$ except $40 \mathrm{~h}$ at $973 \mathrm{~K}$. + and $\square, 22-$ $33 \%$ water in feed; $\square$ and $O, 14 \%$ water. 
bon dioxide gave higher yields at the higher temperatures, although there was loss of selectivity and potassium at long times-on-stream. The material used in Fig. 1 (treatment C) lost $27 \%$ of its potassium and $20 \%$ of its total selectivity to $\mathrm{C}_{2}$ products in $40 \mathrm{~h}$ time-on-stream at $935 \mathrm{~K}$. All subsequent results for nickel-containing catalysts were obtained using procedure $\mathrm{C}$.

The effect of the water content of the feed on the performance of nickelcontaining catalysts is shown in Fig. 2 for a $\mathrm{K} .1 / \mathrm{Ca} .8 / \mathrm{Ni}$ catalyst. It is evident that increasing the concentration of water in the feed increased the $\mathrm{C}_{2}$ yield. This effect was nonlinear; the largest increase in yield occurred when the water content was increased from 0 to $25 \%$, with smaller increases in yield observed upon further increases in water content. Total activity also depended on water content; in a related experiment, a step change in feed composition from 65 to $30 \%$ water at $873 \mathrm{~K}$ caused a decrease in methane conversion from 32 to $19 \%$ and in $\mathrm{C}_{2}$ selectivity from 20 to $13 \%$.

Any nickel-containing catalyst operated in the absence of water in the feed ultimately displayed only reforming, combustion, and coking activity, with reforming to carbon monoxide and hydrogen being the dominant reaction. At these conditions there was rapid carbon accumulation at short times-on-stream. The conversion from an OCM to a reforming catalyst was rapid (less than 3 h) and was accompanied by large increases in $\mathrm{C}_{1}$ conversion, $\mathrm{CO} / \mathrm{CO}_{2}$ ratio, and hydrogen production. The presence of $10 \%$ water in the feed was found adequate to prevent this transformation.

A catalyst presaturated with water for a long period could still catalyze OCM for several hours, even after helium was substituted for water. A catalyst's behavior subsequent to such a step-change is shown in Fig. 3. The yields shown are still typical of a catalyst with ca. $25 \%$ water in the feed (compare to Fig. 2).

The normal $\mathrm{C}_{1} / \mathrm{O}_{2}$ ratio used in OCM reaction experiments was about 2.5. At these conditions the maximum steady-state $\mathrm{C}_{2}$ selectivity for nickel-containing catalysts was about $40 \%$. This maximum was obtained with potassium-

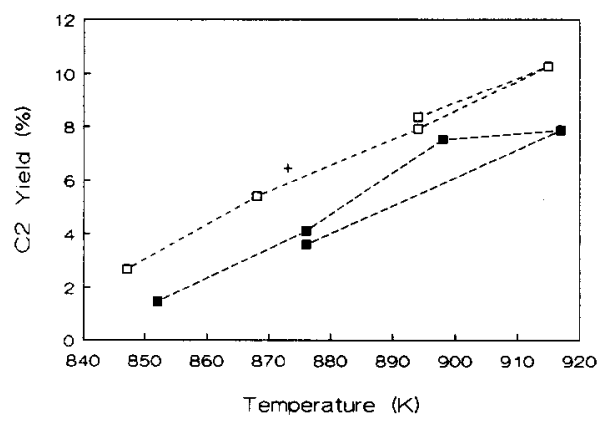

Fig. 2. Effect of variable water content, $K .1 / \mathrm{Ca} .8 / \mathrm{Ni}$ catalyst, $\mathrm{C}_{1} / \mathrm{O}_{2} \mathrm{ca} .2 .5 ;(+) 65$ mol-\% water in feed, ( $\square$ ) $46 \%$, ( $\square$ ) $25 \%$. 


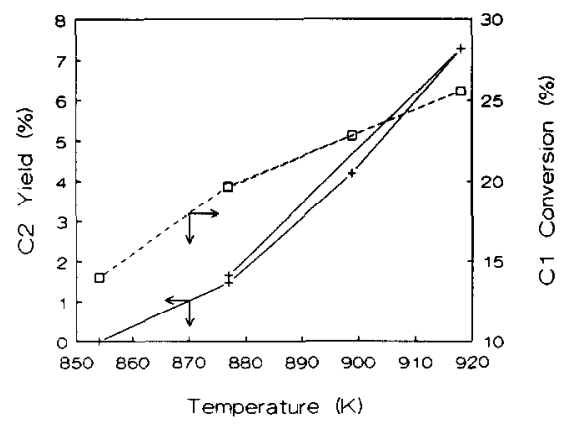

Fig. 3. Behavior of K.1/Ca.8/Ni catalyst after step change in feed content from $25 \% \mathrm{H}_{2} \mathrm{O}$ to $25 \%$ $\mathrm{He}, \mathrm{C}_{1} / \mathrm{O}_{2}$ ca. $2.5 ;(+)$ percent $\mathrm{C}_{2}$ yield, $(\square)$ percent $\mathrm{C}_{1}$ conversion. The water pretreatment was for $24 \mathrm{~h}$ at $873 \mathrm{~K}$. Each data point corresponds to ca. $2 \mathrm{~h}$ time-on-stream.

TABLE 1

Detailed results for most selective catalysts

\begin{tabular}{lllcc}
\hline $\mathrm{K} / \mathrm{Ca}$ & 0.05 & 0.05 & 0.17 & 0.44 \\
$\mathrm{Ca} / \mathrm{Ni}$ & - & - & 0.75 & 1.32 \\
$\mathrm{~K} / \mathrm{Ni}$ & - & - & 0.13 & 0.58 \\
Temperature & 935 & 935 & 915 & 934 \\
$(\mathrm{~K})$ & & & & \\
$\mathrm{C}_{1} / \mathrm{O}_{2}$ & 53 & 3.3 & 2.7 & 2.3 \\
Water $^{(\%)}$ & 38 & 34 & 46 & 28 \\
WHSV $^{a}$ & 0.40 & 0.40 & 0.40 & 0.39 \\
TO $^{b}$ & $>4$ & $>4$ & $>1.6$ & $>3.5$ \\
STY $^{c}$ & 0.012 & 0.018 & 0.042 & 0.045 \\
HC Sel. $^{d}(\%)$ & 67 & 37 & 39 & 37 \\
HC Sel. (\%) & 55 & 31 & 25 & 0 \\
$\mathrm{C}_{1}$ Conv. (\%) & 4.5 & 13.6 & 26.6 & 30.0 \\
\hline
\end{tabular}

n.r. not reported

${ }^{a}$ Methane WHSV; the actual reactor residence time is about $1 \mathrm{~s}$.

${ }^{b}$ Number of turnovers based on average conversion, grams methane converted per gram catalyst.

${ }^{c}$ Space-time yield, grams methane converted to higher hydrocarbons per gram catalyst per hour.

${ }^{d}$ Highest selectivity reported; lowest selectivity in next row; in this work, only $\mathrm{C}_{2}$ hydrocarbons were analyzed.

e Converts to reforming catalyst $\left(\mathrm{CO}+\mathrm{H}_{2}\right.$ products) after several hours on-stream at this temperature.

containing catalysts of low (less than 4 ) $\mathrm{Ca} / \mathrm{Ni}$ at complete oxygen conversion, and at 903-933 K. Claims of much higher selectivities have been made for similar catalysts by Heinemann and coworkers at similar conditions $[7,8]$. Table 1 gives detailed, averaged results for our most selective catalysts. Compared to results of Heinemann and coworkers, our space-time yields (production rates of higher hydrocarbons) were higher, and our catalysts were kept on stream for relatively longer periods, because we employed a six times higher 
space velocity. At short times-on-stream, with catalysts of $\mathrm{Ca} / \mathrm{Ni}$ ratio $>2$, we also observed high selectivities at lower than $873 \mathrm{~K}$ (similar to results in refs. 7 and 8 ). However, these selectivities did not last for a complete turnover based on the weight of catalyst used. These transient, initial selectivities are reported in Table 2.

The effects of $\mathrm{C}_{1} / \mathrm{O}_{2}$ ratio on the performance of $\mathrm{K} .6 / \mathrm{Ca} 1.3 / \mathrm{Ni}$ are shown in Fig. 4. The methane partial pressure for these experiments was kept constant by the addition of helium at the higher $\mathrm{C}_{1} / \mathrm{O}_{2}$ ratios. It is noteworthy that for the nickel-containing catalysts both $\mathrm{C}_{2}$ yields and $\mathrm{C}_{2}$ selectivities increased as the $\mathrm{C}_{1} / \mathrm{O}_{2}$ ratio decreased. This behavior is in contrast to most OCM catalysts, whose $\mathrm{C}_{2}$ selectivities decrease monotonically while yields either decrease or go through a maximum (e.g., $\mathrm{Li} / \mathrm{MgO}$ [16], $\mathrm{Sm}_{2} \mathrm{O}_{3}$ [17], $\mathrm{PbO} / \mathrm{MgO}$ [18], $\mathrm{Mn} / \mathrm{Na}_{4} \mathrm{P}_{2} \mathrm{O}_{7} / \mathrm{SiO}_{2}[19]$ ).

The potassium content of the nickel catalysts appeared to affect $\mathrm{C}_{2}$ production only slightly. This is evident from Fig. 5 upon comparing the upper two

\section{TABLE 2}

Initial selectivities for catalysts of high $\mathrm{Ca} / \mathrm{Ni}$

$\mathrm{C}_{1} / \mathrm{O}_{2}=2.3-2.7$

\begin{tabular}{llcccc}
\hline Catalyst & $\begin{array}{l}\text { Temperature } \\
(\mathrm{K})\end{array}$ & $\begin{array}{l}\mathrm{C} \mathrm{Bal}^{a} \\
(\%)\end{array}$ & $\begin{array}{l}\mathrm{H}_{2} \mathrm{O} \\
(\%)\end{array}$ & $\begin{array}{l}S_{\mathrm{C}_{2}} \\
(\%)\end{array}$ & $\begin{array}{l}\mathrm{C}_{1} \text { Conv. } \\
(\%)\end{array}$ \\
\hline $\mathrm{K} .05 / \mathrm{Ca} 5 / \mathrm{Ni}$ & 863 & 58 & 35 & 54 & 3.6 \\
$\mathrm{~K} .05 / \mathrm{Ca} 5 / \mathrm{Ni}^{b}$ & 863 & 102 & 35 & 0.0 & 3.7 \\
$\mathrm{~K} .6 / \mathrm{Ca} 11 / \mathrm{Ni}^{b}$ & 852 & 85 & 41 & 72 & 3.6 \\
$\mathrm{~K} .6 / \mathrm{Ca} 11 / \mathrm{Ni}^{b}$ & 852 & 99 & 43 & 0 & 4.5 \\
$\mathrm{~K} .6 / \mathrm{Ca} 11 / \mathrm{Ni}^{\mathrm{c}}$ & 852 & 103 & 44 & 30 & 0.84 \\
\hline
\end{tabular}

${ }^{a} 100 \times$ (carbon out)/(carbon in).

${ }^{b}$ After $12 \mathrm{~h}$ time-on-stream.

${ }^{c}$ After $12 \mathrm{~h}$ time-on-stream and extra $24 \mathrm{~h}$ oxygen treatment at $700^{\circ} \mathrm{C}$.

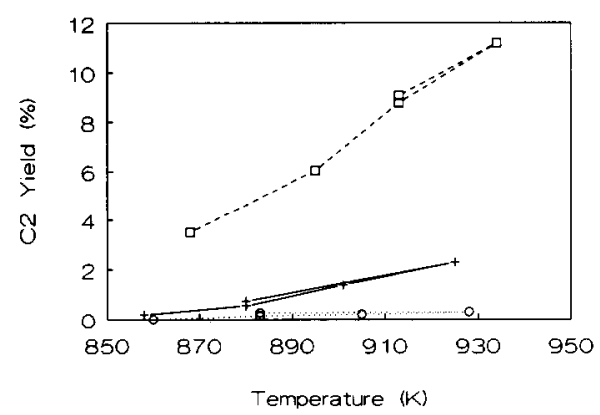

Fig. 4. Effect of $\mathrm{C}_{1} / \mathrm{O}_{2}$ ratio, K.6/Ca1.3/Ni catalyst, 24-29\% water in feed; ( $\square$ ) $\mathrm{C}_{1} / \mathrm{O}_{2}=2.3$, (+) 4.6, (O) 44 . 


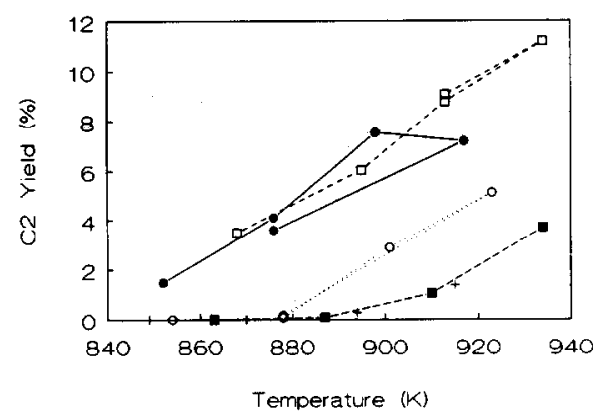

Fig. 5. $\mathrm{C}_{2}$ yield for five different catalyst compositions at $24-35 \%$ water in the feed, $\mathrm{C}_{1} / \mathrm{O}_{2}$ ca. 2.5; (O) K.1/Ca.8/Ni, (口) K.6/Ca1.3/Ni, (O) K.2/Ca10/Ni, (口) K.05/Ca5/Ni, (+) K.05/Ca.

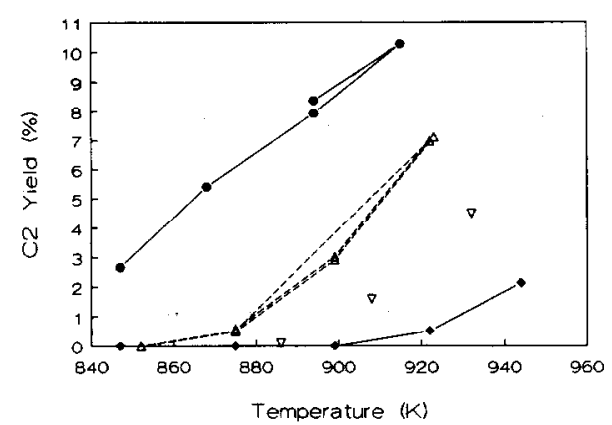

Fig. 6. $\mathrm{C}_{2}$ yield for four different catalyst compositions at $41-47 \%$ water in the feed, $\mathrm{C}_{1} / \mathrm{O}_{2}$ ca. 2.5; (๑) $\mathrm{K} .1 / \mathrm{Ca} .8 / \mathrm{Ni},(\Delta) \mathrm{K} .6 / \mathrm{Ca} 11 / \mathrm{Ni},(\nabla) \mathrm{K} 1.2 / \mathrm{Ca} 4 / \mathrm{Ni},(\diamond) \mathrm{K} 1.5 / \mathrm{Ni}$.

curves describing the performance of two catalysts of similar $\mathrm{Ca} / \mathrm{Ni}$ ratio. It should be noted that the K.6/Ca1.3/Ni catalyst became less selective when kept for several hours at temperatures higher than $930 \mathrm{~K}$, so even at high temperature the differences between this catalyst and $\mathrm{K} .1 / \mathrm{Ca} .8 / \mathrm{Ni}$ may not be significant.

The more important determinant of $\mathrm{C}_{2}$ yield was $\mathrm{Ca} / \mathrm{Ni}$ ratio, as seen upon examination of both Figs. 5 and 6 . In both figures it is evident that materials of low (less than 4) $\mathrm{Ca} / \mathrm{Ni}$ ratio were superior, and that materials either without nickel (the K.05/Ca results in Fig. 5) or calcium (the K1.5/Ni results in Fig. 6) were poor catalysts. The behavior of potassium/calcium/nickel materials of high $\mathrm{Ca} / \mathrm{Ni}$ ratio fell between these two groups. The maximum selectivity of the high $\mathrm{Ca} / \mathrm{Ni}$ catalysts was only $32 \%$.

At high $\mathrm{C}_{1} / \mathrm{O}_{2}$ ratios the yield improved for the $\mathrm{K} .05 / \mathrm{Ca}$ catalyst, as shown in Fig. 7. Note that this behavior of increasing yield with respect to $C_{1} / O_{2}$ ratio (at roughly constant methane partial pressure) is exactly opposite that found for the nickel-containing catalysts. A maximum selectivity of $67 \%$ was found for this catalyst, at its highest temperature and oxygen conversion. Even at 


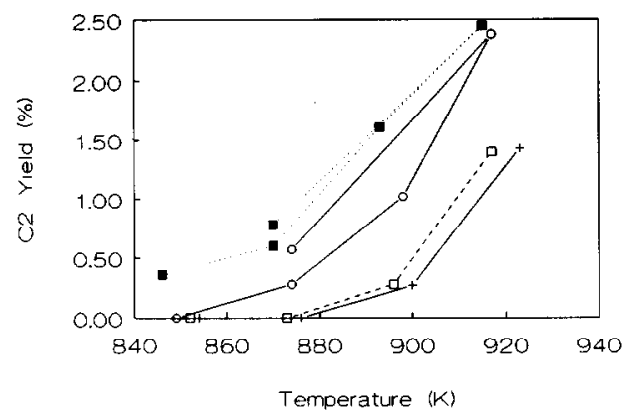

Fig. 7. Effect of $\mathrm{C}_{1} / \mathrm{O}_{2}$ ratio and water content of the feed, K.05/Ca catalyst; $(+) \mathrm{C}_{1} / \mathrm{O}_{2}=3.3$, $36 \%$ water; ( $\square$ ) $3.3,27 \%$; (O) $53,22 \%$; ( $) 52,38 \%$.

\section{TABLE 3}

Bulk phases identified by XRD

\begin{tabular}{lll}
\hline Catalyst & Major phases & Minor phases \\
\hline K.05/Ca, fresh & $\mathrm{CaO}, \mathrm{Ca}(\mathrm{OH})_{2}$ & $\mathrm{CaCO}$, tr. $\mathrm{KO}_{2}$ \\
K.05/Ca, used & $\mathrm{Ca}(\mathrm{OH})_{2}$ & $\mathrm{Ca}(\mathrm{CO})_{3}$ \\
K.2/Ca10/Ni, fresh & $\mathrm{CaCO}_{3}, \mathrm{CaO}$ & $\mathrm{Ca}(\mathrm{OH})_{2}, \mathrm{NiO}$ \\
K.2/Ca10/Ni, used & $\mathrm{CaCO}$ & $\mathrm{Ca}(\mathrm{OH})_{2}, \mathrm{NiO}, \mathrm{CaO}$ \\
K.05/Ca5/Ni, fresh & $\mathrm{CaO}, \mathrm{NiO}$ & $\mathrm{Ca}(\mathrm{OH})_{2}, \mathrm{CaCO}$, tr. NiOOH \\
K.5/Ca4/Ni, fresh & $\mathrm{CaO}, \mathrm{NiO}$ & $\left.\mathrm{Ca}(\mathrm{CO})_{3}\right)$,tr. $\mathrm{NiOOH}$ \\
K.5/Ca4/Ni, used & $\mathrm{CaO}, \mathrm{NiO}, \mathrm{Ca}\left(\mathrm{CO}_{3}\right)$ & $\mathrm{Ca}(\mathrm{OH})_{2}$, tr. NiOOH \\
K.1/Ca.8/Ni, fresh & $\mathrm{NiO}, \mathrm{CaO}, \mathrm{Ca}(\mathrm{OH})_{2}$ & $\mathrm{CaCO}$, tr. $\mathrm{NiOOH}$ \\
K.1/Ca.8/Ni, used & $\mathrm{NiO}, \mathrm{CaCO}$ & $\mathrm{CaO}$, tr. $\mathrm{NiOOH}, \mathrm{tr} . \mathrm{K}_{2} \mathrm{Ca}\left(\mathrm{CO}_{3}\right)_{2}$ \\
K.6/Ca1.3/Ni, fresh & $\mathrm{NiO}, \mathrm{CaO}, \mathrm{Ca}(\mathrm{CO})_{3}$ & $\mathrm{NiOOH}, \mathrm{CaO}, \mathrm{K}_{2} \mathrm{CaCO}_{3}$ \\
K.6/Ca1.3/Ni, used & $\mathrm{NiO}, \mathrm{CaCO}, \mathrm{Ca}(\mathrm{OH})_{2}$ & $\mathrm{CaO}, \mathrm{K}_{2} \mathrm{Ca}\left(\mathrm{CO}_{3}\right)_{2}, \mathrm{CaO}_{2}$ \\
\hline
\end{tabular}

$\operatorname{Tr} .=$ Trace amount.

$\mathrm{C}_{1} / \mathrm{O}_{2}>50$, oxygen conversions were less than $100 \%$ until $>910 \mathrm{~K}$. However, water was reacted and hydrogen formed. For example, with $38 \%$ water in the feed, $2-7 \%$ of the water was depleted, in contrast with the nickel-containing catalysts which always produced water.

\section{Catalyst characterization}

The bulk phases in the catalysts were determined by XRD. In Table 3, "fresh" catalyst denotes a calcined material not yet used in a kinetics experiment. A large increase in carbonate content was evident when used catalysts were compared to fresh ones by either XRD or TGA. Also, a new minor phase either appeared or grew in used materials of low $\mathrm{Ca} / \mathrm{Ni}$; this phase was identified as $\mathrm{K}_{2} \mathrm{Ca}\left(\mathrm{CO}_{3}\right)_{2}$. No other potassium-containing phase could be identified by XRD in materials containing nickel. 
Some fresh and used catalysts were further examined by DSC using either air, $50 \% \mathrm{H}_{2} / 50 \% \mathrm{~N}_{2}$, or carbon dioxide (to $773 \mathrm{~K}$ ) followed by oxygen (to 993 $\mathrm{K}$ ) carrier gases. Already calcined materials were stable in air up to $1073 \mathrm{~K}$ when examined by DSC. Two samples (K.01/Ca.2/Ni and $\mathrm{K} .1 / \mathrm{Ca} 1.7 / \mathrm{Ni})$ were tested, and no transitions noted unless carbon dioxide had been used in the calcinations. When treated with $\mathrm{H}_{2} / \mathrm{N}_{2}$, however, several endotherms were found as shown in Fig. 8 (endothermic transitions plotted as negative) for some used catalysts and an $\mathrm{NiO}$ (Baker, reagent) standard. Only the highest temperature, broad endotherm (which was incomplete even at $1073 \mathrm{~K}$ ) cannot be fully attributed to carbonate decomposition or water loss; the lower-temperature endotherms were also found for materials which were temperatureprogrammed using carbon dioxide, followed by oxygen.

The final in-situ calcinations of materials with different potassium contents were also performed in both the DSC and the TGA. The purpose here was to observe the decomposition of the $\mathrm{KNO}_{3}$ and the possible incorporation of potassium into a nickel oxide. Some of these results are shown in Fig. 9; results for a material with no nickel (K.05/Ca) and no potassium $(\mathrm{Ca} 4 / \mathrm{Ni})$ are shown for comparison purposes. The primary low-temperature endotherm at $630-710$ $\mathrm{K}$ can be attributed to the decomposition of $\mathrm{KNO}_{3}$, because this endotherm is absent from $\mathrm{Ca} 4 / \mathrm{Ni}$ and this temperature range spans the reported decomposition temperature of the pure compound, $673 \mathrm{~K}$ [20]. The weight loss in nitrogen was $5.7 \%$ vs. $5.6 \%$ calculated for decomposition to $\mathrm{K}_{2} \mathrm{O}$. For materials containing both potassium and nickel there is a broad exotherm noticeable in the $720-930 \mathrm{~K}$ range, especially for samples calcined in oxygen. The TGA results confirmed that this exotherm was associated with small (less than $1 \%$ ) weight gains; however, the weight gains were much larger when $\mathrm{O}_{2} / \mathrm{CO}_{2}$ mixtures were used.

These results confirmed that $\mathrm{KNO}_{3}$ was decomposed at the calcination temperatures, even in nitrogen atmosphere. We hypothesize that the exotherm

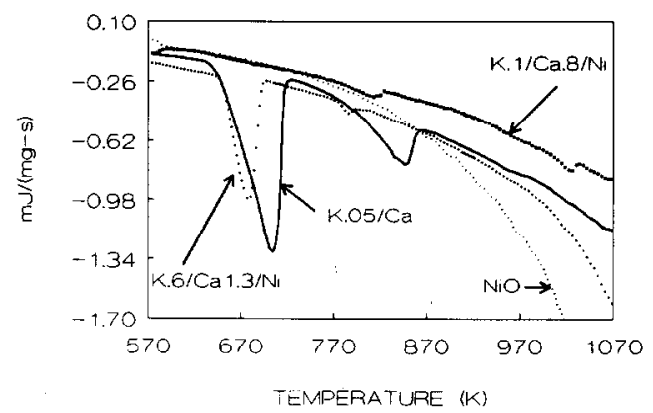

Fig. 8. Example temperature-programmed reduction spectra of used catalysts in a DSC; solid curve: $\mathrm{K} .05 / \mathrm{Ca}$, ( $\square$ ) $\mathrm{K} .1 / \mathrm{Ca} .8 / \mathrm{Ni},(+) \mathrm{K} .6 / \mathrm{Ca} 1.3 / \mathrm{Ni}$; dotted curve: NiO. Carrier gas is $50 \%$ $\mathrm{H}_{2} / 50 \% \mathrm{~N}_{2}$ at $30 \mathrm{~cm}^{3} / \mathrm{min}$. Endothermic transitions plotted as negative. 


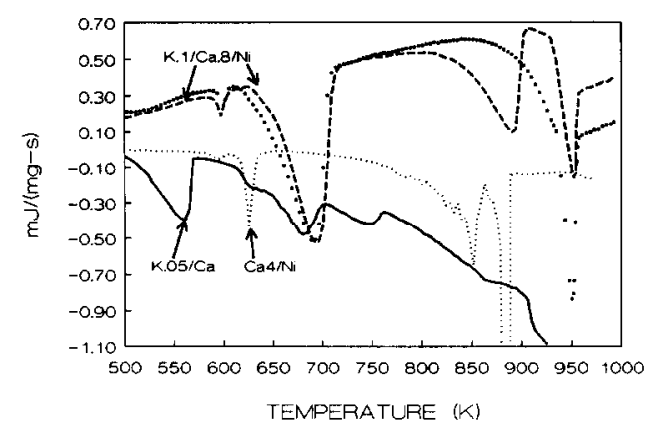

Fig. 9. DSC of calcinations with oxygen of potassium/calcium/nickel oxides, all prepared using $\mathrm{KNO}_{3}$; (口) $\mathrm{K} .1 / \mathrm{Ca} .8 / \mathrm{Ni}$; dashed curve: same but nitrogen carrier gas; dotted curve: $\mathrm{Ca} 4 / \mathrm{Ni}$; solid curve: K.05/Ca. Carrier gas flow is $30 \mathrm{~cm}^{3} / \mathrm{min}$. Endothermic transitions plotted as negative.

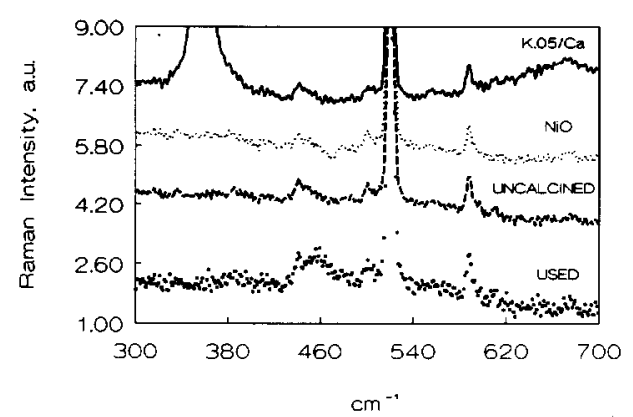

Fig. 10. Raman spectra of K.1/Ca.8/Ni and comparison standards; ( $\square$ ) used catalyst; dashed curve: uncalcined catalyst; dotted curve: $\mathrm{NiO}$; solid curve: $\mathrm{K} .05 / \mathrm{Ca}$, used.

subsequent to this decomposition represents the dissolution of liberated $\mathrm{K}_{2} \mathrm{O}$ in the $\mathrm{NiO}_{x}$. Although this exothermic transformation was complicated by carbonation in the presence of carbon dioxide at temperatures lower than $770 \mathrm{~K}$ and decarbonation at higher temperatures, we note in support of our hypothesis that the Ca4/Ni sample showed no exotherm at all (Fig. 9).

Raman spectra in the range $300-700 \mathrm{~cm}^{-1}$ for the $\mathrm{K} .1 / \mathrm{Ca} .8 / \mathrm{Ni}$ catalyst were compared to spectra of $\mathrm{NiO}$ and $\mathrm{K} .05 / \mathrm{Ca}$ as shown in Fig. 10. The bands centered at 441, 520 and $587 \mathrm{~cm}^{-1}$ were common to all samples and can therefore be attributed to sample fluorescence. However, two important features were noted: (1) the strong carbonate bands at 357 and $675 \mathrm{~cm}^{-1}$ did not appear in materials of low $\mathrm{Ca} / \mathrm{Ni} ;(2)$ in calcined and used nickel-containing catalysts there was noticeable growth of a band centered at $460-470 \mathrm{~cm}^{-1}$.

\section{DISCUSSION}

The low (less than 4) $\mathrm{Ca} / \mathrm{Ni}$ catalysts exhibited low-temperature activity, with yields of $5-8 \%$ possible even at $890 \mathrm{~K}$; such yields would require about 
$970 \mathrm{~K}$ using a $\mathrm{MgO}$-based $\mathrm{OCM}$ catalyst such as $\mathrm{Li} / \mathrm{Sn} / \mathrm{MgO}$ [12]. However, the selectivities obtained here were low, about $40 \%$ maximum vs. $80 \%$ maximum for $\mathrm{Li} / \mathrm{Sn} / \mathrm{MgO}$, and large amounts of catalyst were required.

Results in Table 2 suggest that the high $\mathrm{C}_{2}$ selectivities obtained using catalysts of high $\mathrm{Ca} / \mathrm{Ni}$ at low temperature were transient. Loss of low-temperature activity coincided with improvement in the carbon balance, suggesting bulk carbonate formation. This was confirmed by XRD (Table 3 ) and Raman results showing growth of a bulk $\mathrm{Ca}(\mathrm{CO})_{3}$ phase upon use. It is noteworthy that $\mathrm{C}_{2}$ production at these conditions ceased completely; therefore, these very active sites for $\mathrm{C}_{2}$ production were poisoned.

The results of the calcination experiments performed in the DSC (Fig. 9) support the above interpretation. Treatment with oxygen or nitrogen resulted in an endotherm at higher than $870 \mathrm{~K}$ that is attributed to carbonate decomposition by analogy with pure calcite [21-23]. Furthermore, the transient $\mathrm{C}_{2}$ selectivities at lower than $873 \mathrm{~K}$ were also observed with $\mathrm{K} .05 / \mathrm{Ca}$, but not with nickel-containing catalysts of low $\mathrm{Ca} / \mathrm{Ni}$. Putting these observations together, we conclude that the very active sites for transient $\mathrm{C}_{2}$ formation are associated with carbonate-free potassium/calcium oxide. For materials of low $\mathrm{Ca} / \mathrm{Ni}$, these sites were not present, because the high $\mathrm{C}_{2}$ selectivities were not observed even when carbon dioxide was not used in the final calcination (e.g., procedures $\mathrm{A}$ and B of Fig. 1).

For K.05/Ca also, no $\mathrm{C}_{2}$ products were found at lower than $873 \mathrm{~K}$ after a satisfactory carbon balance was achieved. However, this catalyst could produce $\mathrm{C}_{2}$ 's at high selectivity and at space-time yields larger than those previously reported [8] when the temperature was increased. Increasing the $\mathrm{C}_{1} / \mathrm{O}_{2}$ ratio had these same effects.

Certain aspects of the structure of the selective phase of the potassium/ calcium/nickel oxides (low $\mathrm{Ca} / \mathrm{Ni}$ ) can be inferred from the results. Nickel is important in generating a more active catalyst (Fig. 5), as is calcium (Fig. 6). There was no evidence of bulk potassium oxides, hydroxides, or carbonates by XRD, even for K.6/Ca1.3/Ni where potassium made up $10.5 \mathrm{wt} .-\%$ of the calcined catalyst. Therefore, all of the potassium, except for the seemingly small amounts in $\mathrm{K}_{2} \mathrm{Ca}\left(\mathrm{CO}_{3}\right)_{2}$, was dissolved in either a primarily nickel oxide or a primarily $\mathrm{CaO} / \mathrm{CaCO}_{3}$ phase. We note that alkalis can be readily included in $\mathrm{NiO}[24]$ and $\mathrm{NiOOH}[25,26]$ in oxidizing atmosphere at low temperature, and bulk alkali nickel oxides can be formed $[27,28]$.

The addition of small amounts of potassium to nickel reforming catalysts reduces turnover frequencies for methane steam reforming by two orders of magnitude at $773 \mathrm{~K}$ [29], in agreement with our finding of no obvious steam reforming with the nickel-containing catalysts at normal reaction conditions. With these materials we observed: (a) minimal hydrogen production; (b) low $\mathrm{CO} / \mathrm{CO}_{2}$ ratios; (c) no net water consumption; (d) catalyst stability at water/ carbon ratios as low as 0.14 , while the minimum water/carbon ratios to prevent 
carbon deposition in methane steam reforming are ca. 0.3-0.4 [30]. However, conditions (a) and (c) were not fulfilled for K.05/Ca; these differences and the differing behavior with respect to $\mathrm{C}_{1} / \mathrm{O}_{2}$ ratio again suggest that the nickelcontaining catalysts are fundamentally different. The onset of noticeable steam reforming activity for the nickel-containing catalysts, at higher than $930 \mathrm{~K}$, coincided with complete loss of $\mathrm{C}_{2}$ yield.

The above discussion ignores the $\mathrm{CaO} / \mathrm{CaCO}_{3}$, however. Our data are insufficient to explain fully the role of calcium in these catalysts. At the synthesis conditions used here a single phase alkaline earth nickel oxide could not be formed; only solid solutions of $\mathrm{Ni} / \mathrm{CaO}$ and $\mathrm{Ca} / \mathrm{NiO}$ with less than 2 wt.- $\%$ solubility of the guest cation in either phase [31] would be possible, if potassium did not greatly affect these solubilities. As $\mathrm{CaO}$ by itself is a poor catalyst at these conditions [8], it is likely that potassium improves the solubility of nickel in $\mathrm{CaO}$ or calcium in $\mathrm{NiO}_{x}$, or both.

The evidence that some $\mathrm{Ca}^{2+}$ must be associated with a potassium nickel oxide phase can be summarized as follows:

(1) the poor catalytic performance of $\mathrm{K} 1.5 / \mathrm{Ni}$ (Fig. 6);

(2) the absence of (transient) high selectivities at lower than $873 \mathrm{~K}$ for catalysts of low $\mathrm{Ca} / \mathrm{Ni}$;

(3) the temperature-programmed reduction (TPR) results (Fig. 8) showing that calcium-containing catalysts are stable to reduction of $\mathrm{NiO}$ to nickel; these results are analogous to the known effects of $\mathrm{MgO}$ on the reducibility of $\mathrm{NiO}[32,33]$;

(4) the Raman spectrum of used K.1/Ca.8/Ni (Fig. 10) showing the relative absence of the carbonate buildup so evident for materials of high $\mathrm{Ca} / \mathrm{Ni}$.

For both our potassium/calcium/nickel catalysts and those of Pereira er al. [7], $\mathrm{C}_{2}^{+}$selectivity decreased at temperatures higher than ca. $930 \mathrm{~K}$, but not irreversibly unless the catalysts remained at high temperature for more than a few hours (e.g., see the repeat measurements in Figs. 1, 2, and 5). Such behavior suggests an active phase or surface based on a hydroxide or adsorbed water; alkali inclusion does promote nickel oxyhydroxide formation [24,25,34]. Wet $\mathrm{A}_{0.2} \mathrm{NiO}_{2}$ alkali nickelates are indistinguishable by $\mathrm{XRD}$ from the material denoted $\gamma-\mathrm{NiOOH}$, some of whose major reflections appear in some of the nickelcontaining catalysts, although the XRD results were not conclusive on this point. Because nickel oxyhydroxides are reduced to $\mathrm{NiO}$ in strongly reducing atmospheres, we might expect an increasing $\mathrm{C}_{1} / \mathrm{O}_{2}$ ratio to affect adversely the nickel-containing catalysts, as was the case here (Fig. 4). The completely opposite behavior of the K.05/Ca catalyst (Fig. 7) suggests that the behavior observed in Fig. 4 must be associated with a nickel-containing phase.

The Raman band growth in the $470-480 \mathrm{~cm}^{-1}$ region (Fig. 10) is consistent with our hypothesis on the active surface. The Raman spectrum of pure NiO 
features bands at 460 and $500 \mathrm{~cm}^{-1}$ of similar intensity [35]. These bands were present both for the uncalcined catalyst and for the $\mathrm{NiO}$ standard. The formation of alkali-containing nickel oxyhydroxides by the oxidation of $\mathrm{Ni}(\mathrm{OH})_{2}$ electrodes in alkaline medium results in the appearance of a band at $470-480 \mathrm{~cm}^{-1}$, attributed to higher valent nickel oxyhydroxides [36,37]. The band at $502 \mathrm{~cm}^{-1}$ grew imperceptibly upon calcination and use, so the growth of intensity at $470-480 \mathrm{~cm}^{-1}$ was not merely a result of large differences in the fraction of total $\mathrm{NiO}_{x}$.

Extensive reduction to bulk nickel can probably be excluded as a cause of deactivation on the basis of the TPR results (Fig. 8). The magnitudes of the high-temperature (incomplete at $1073 \mathrm{~K}$ ) endotherm for most of the used nickel-containing catalysts were actually smaller than the comparable endotherm of $\mathrm{K} .05 / \mathrm{Ca}$. This was also true of unused but calcined samples. The comparable magnitude for $\mathrm{K} .6 / \mathrm{Ca} 1.3 / \mathrm{Ni}$ was slightly larger, but this is to be expected on the basis of its higher potassium content, because potassium loss also took place at temperatures higher than $930 \mathrm{~K}$.

\section{CONCLUSIONS}

(1) The nickel-containing catalysts of low $\mathrm{Ca} / \mathrm{Ni}$ ratio (less than 4) are active for $\mathrm{OCM}$ in the presence of at least $10 \%$ water in the feed, but selectivities are low (maximum ca. 40\%). Both activities and selectivities increase as the water content of the feed increases. Such catalysts contain an active potassium/calcium/nickel oxide which is hydrated and probably contains some $\mathrm{Ni}^{3+} / \mathrm{Ni}^{4+}$. The observed loss of selectivity as $\mathrm{C}_{1} / \mathrm{O}_{2}$ is increased may be related to reduction of this higher valent nickel to $\mathrm{NiO}$.

(2) A catalyst with no nickel is far less active but capable of much higher selectivity (maximum $67 \%$ ), which increases with respect to $\mathrm{C}_{1} / \mathrm{O}_{2}$ ratio.

(3) Catalysts of high (higher than 4) $\mathrm{Ca} / \mathrm{Ni}$ ratio are also less active, and exhibit lower selectivities as well.

(4) Calcination of potassium/calcium/nickel oxides in a $\mathrm{CO}_{2} / \mathrm{O}_{2}$ mixture gives a catalyst with better high-temperature stability, although loss of $\mathrm{C}_{2}$ selectivity and potassium still takes place upon prolonged use at higher than 930 $\mathrm{K}$.

(5) High $\mathrm{C}_{2}$ selectivities at lower than $873 \mathrm{~K}$ are apparently associated with carbonate-free potassium/calcium oxides. The active sites associated with this behavior are poisoned by carbonate buildup.

\section{ACKNOWLEDGEMENTS}

One of us $(\mathrm{KD})$ acknowledges the receipt of fellowships from the Netherlands Energy Organization (NWO) and the Netherlands-America (Fulbright) Commission for Educational Exchange. This work was supported by 
the EC Joule project and by the Louisiana Educational Quality Support Fund under contract number RD-B-5.

\section{REFERENCES}

1 R.K. Ungar, X. Zhang and R.M. Lambert, Appl. Catal., 42 (1988) L1.

2 M. Hatano and K. Otsuka, J. Chem. Soc. Faraday Trans. 1, 85 (1989) 199.

3 J.B. Kimble and J.H. Kolts, Eur. Pat. Appl., 335995 (1989).

4 T.J. Pickering, J.M. Thomas and P.J. Maddox, in G. Centi and F. Trifiró (Editors), New Developments in Selective Oxidation, Elsevier, Amsterdam, 1989, p. F33.

5 K. Otsuka, M. Hatano and T. Komatsu, Catal. Today, 4 (1989) 409.

6 E.E. Miro, J.M. Santamaria and E.E. Wolf, J. Catal., 451 (1990) 465.

7 P. Pereira, S.H. Lee, G.A. Somorjai and H. Heinemann, Catal. Lett., 6 (1990) 255.

8 J. Rasko, P. Pereira, G.A. Somorjai and H. Heinemann, Catal. Lett., 9 (1991) 395.

9 D.W. Leyshon, US Pat., 4801762 (1989).

10 A.M. Gaffney, C.A. Jones and J.A. Sofranko, US Pat., 4795842 (1989).

11 S.J. Korf, J.A. Roos, L.J. Veltman, J.G. van Ommen and J.R.H. Ross, Appl. Catal., 56 (1989) 119.

12 S.J. Korf, J.A. Roos, J.A. Vreeman, J.W.H.C. Derksen, J.G. van Ommen and J.R.H. Ross, Catal. Today, 6 (1990) 417.

13 S. Bartsch, J. Falkowski and H. Hofmann, Catal. Today, 4 (1989) 421.

14 K. Aika, M. Tajima, M. Isobe and T. Onishi, Proc. 8th Intl. Cong. Catal., Berlin, 1988, Vol. 3, Verlag-Chemie, Weinheim, 1988, p. 335.

15 G.D. Moggridge, J.P.S. Badyal and R.M. Lambert, J. Phys. Chem., 94 (1990) 508.

16 J.H. Edwards, R.J. Tyler and S.D. White, Energ. Fuels, 4 (1990) 85.

17 S.J. Korf, J.A. Roos, J.M. Diphoorn, R.H.J. Veehof, J.G. van Ommen and J.R.H. Ross, Catal. Today, 4 (1989) 279.

18 K. Asami, S. Hashimoto, T. Shikada, K. Fujimoto and H. Tominaga, Ind. Eng. Chem. Res., 26 (1987) 1485.

19 H.P. Withers, C.A. Jones, J.J. Leonard and J.A. Sofranko, US Pat., 4634800 (1987).

20 R.C. Weast (Editor), CRC Handbook of Chemistry and Physics, 66th Ed., CRC Press, Boca Raton, 1985, p.B130.

21 H. Juntgen and K.H. van Heek, in H.R. Oswald and E. Dubler (Editors), Proc. 3rd Intl. Conf. Thermal Analysis, Birkhauser Verlag, Basel, 1972, p. 423.

22 A.O. Wist, in R.F. Schwenker and P.D. Garn (Editors), Proc. 2nd Intl. Conf. Thermal Analysis, Academic, New York, 1969, p. 1095.

23 T. Haga, J.-I. Ozaki, K. Suzuki and Y. Nishiyama, J. Catal., 134 (1992) 107.

24 P.N. Bitjutskii and V.I. Khitrova, Sov. Phys. Crystallogr., 29 (1984) 270.

25 R.S. McEwen, J. Phys. Chem., 75 (1971) 1782.

26 P.N. Bitjutskii, V.I. Khitrova and Z.G. Pinsker, Sov. Phys. Crystallogr., 18 (1974) 613.

27 L.D. Dyer, B.S. Borie, Jr. and G.P. Smith, J. Amer. Chem. Soc., 76 (1954) 1499.

28 M.G. Barker and A.P. Dawson, J. Less Comm. Met., 45 (1976) 323.

29 J.R. Rostrup-Nielsen, J. Catal., 31 (1973) 173.

30 D.E. Ridler and M.V. Twigg, in M.V. Twigg (Editor), Catalyst Handbook, Wolfe, 1989, Ch. 5.

31 T.Y. Tien and L.H. van Vlack, J. Am. Ceram. Soc., 52 (1969) 460.

32 M.H. Tikkanen, B.O. Rosell and O. Wiherg, Acta Chim. Scand., 17, 513(1963).

33 C.-S. Bai, S. Soled, R. Kershaw, K. Dwight and A. Wold, J. Solid State Chem., 96 (1992) 376. 
34 H. Bode, K. Demhelt and J. Witte, Z. Anorg. Chem., 366 (1969) 1.

35 S.S. Chan and I.E. Wachs, J. Catal., 103 (1987) 224.

36 C.A. Melendres, W. Paden, B. Tani and W. Walczak, J. Electrochem. Soc., 134 (1987) 762.

37 J. Desilvestro, D.A. Corrigan and M.J. Weaver, J. Electrochem. Soc., 135 (1988) 885. 